\title{
Understanding Earnings Response Coefficient from Growth Opportunities, Earnings Persistance, and Intellectual Capital; Empirical Study from IDX-30 Indexed Companies
}

\author{
Handi Handi*, Dien Noviany Rahmatika, Baihaqi Fanani \\ Universitas Pancasakti Tegal, Indonesia \\ *Corresponding author. Email: handilakalaka@gmail.com
}

\begin{abstract}
This research aimed to analyze the influence of the earnings response coefficient based on growth opportunities, earnings persistance and intellectual capital in financial statements of IDX-30 companies on 2017 until 2019. The population in this study was 45 companies, with a purposive sampling system obtained 17 samples of companies for 3 periods to 51 financial data. The examination utilized is multiple linear regression analysis methods. The outcomes represent if growth opporturnities didn't affect on earnings response coefficient, earnings persistance influenced earnings response coefficient, and intellectual capital didn't affect on earnings response coefficient. In views of these calibration, this study shows that of the three independent variables, the influence of earnings persistance can trigger stronger market responsiveness, because earnings stability are able to convince investors to react faster in determining investment decisions.
\end{abstract}

Keywords: Growth Opportunities, Earnings Persistance, Intellectual Capital, Earnings Response Coefficient

\section{INTRODUCTION}

The issue of Covid-19 began to spread, in January 2020 the condition of the Indonesian market had begun to experience indolent. Initially the Composite Stock Price Index (JCI) on January $20^{\text {th }}, 2020$ was at the level of 6,245 then weakened by around 5\% and continued to weaken until the end of January 2020 to 5,940 [1].

On March $2^{\text {nd }} 2020$ the government reported the first case of Covid-19 in Indonesia, the impact of IHSG again continued the downtrend to the level of 5,361 [2]. And finally on March $24^{\text {th }}, 2020$, JCI managed to land about $26 \%$ from its initial position in March reached its nadir at the level of 3,937 [3].

The Covid-19 pandemic that is currently sweeping makes investors more moved to put their funds in prudent and resilient companies [4]. Sitinjak observed that the phenomenon of falling stock prices due to the pandemic makes the psychological factors of investors become panic selling and tend to hybrid so that almost all shares in IDX-30 are affected by undervalue even most likely to reach the great sale [5].

Profit information is said to be valuable if the result of the publication of such information gives rise to market reaction [6]. Market reaction that occurs can be clearly seen through fluctuations in the market price (return of shares) of companies that appear at the time of profit news. 
Table 1: IDX-30 Indexed Company Share Price Fluctuations

\begin{tabular}{|c|c|c|c|c|c|c|}
\hline STOCK CODE & PUBLICATION DATE & $\mathbf{t}-2$ & $\mathbf{t}-1$ & $\mathbf{t} 0$ & $\mathbf{t}+\mathbf{l}$ & $\mathbf{t}+\mathbf{2}$ \\
\hline BBNI & $23 / 01 / 2020$ & $\mathrm{Rp} 7.575$ & $\mathrm{Rp} 7.625$ & $\mathrm{Rp} 7.650$ & $\mathrm{Rp} 7.700$ & $\mathrm{Rp} 7.450$ \\
\hline BBCA & $27 / 01 / 2020$ & $\mathrm{Rp} 32.650$ & $\mathrm{Rp} 32.100$ & $\mathrm{Rp} 31.450$ & $\mathrm{Rp} 31.450$ & $\mathrm{Rp} 30.400$ \\
\hline UNTR & $27 / 02 / 2020$ & $\mathrm{Rp} 18.275$ & $\mathrm{Rp} 18.000$ & $\mathrm{Rp} 17.575$ & $\mathrm{Rp} 16.600$ & $\mathrm{Rp} 16.675$ \\
\hline INTP & $20 / 03 / 2020$ & $\mathrm{Rp} 9.950$ & $\mathrm{Rp} 9.275$ & $\mathrm{Rp} 11.125$ & $\mathrm{Rp} 10.350$ & $\mathrm{Rp} 10.350$ \\
\hline GGRM & $02 / 04 / 2020$ & $\mathrm{Rp} 41.100$ & $\mathrm{Rp} 40.050$ & $\mathrm{Rp} 43.975$ & $\mathrm{Rp} 46.650$ & $\mathrm{Rp} 49.825$ \\
\hline
\end{tabular}

The phenomenon that occurs based on the information in the IDX-30 indexed company's stock price fluctuation table above, it appears that there is a dominant price transition around the window event. On January $23^{\text {rd }} 2020$, BBNI share profit was obtained at Rp15,508,583,000,000 [7]. While in the previous era BBNI only got Rp15,091,763,000,000 [8], meaning that when BBNI reported an annual profit that increased by $2.76 \%$, there was a market reaction through the increase in BBNI share price at $t+1$. However, unlike UNTR on February $27^{\text {th }} 2020$, it reported profit information of Rp11,134,641,000,000 [9], where this nominal value is lower by $3.16 \%$ when compared to the previous year which was able to reach Rp11,498,409,000,000 [10], so that the market reaction that appears in UNTR can be seen through the gradually decreasing UNTR share price.

This phenomenon hints that there is a differentiation in investor response to the company's profit statement [11]. The news of the company's profit in the capital market will cause the market to react. Profit information can be said to have useful value for investor decision making if profit and return have a direct bond [12]. On $27^{\text {th }}$ February 2020 BBCA reported a profit of $10.52 \%$ [13], then continued on March 20th 2020 INTP reported a profit that could be successful to reach $60.16 \%$ [14], and the following month on April $2^{\text {nd }}, 2020$ GGRM also reported a profit increase of $39.62 \%$ [15]. However, it turns out that the market reaction seen in table 1 actually shows fluctuations in stock prices that tend to decline. This difference shows that the increase in profit is not always accompanied by positive fluctuations in the share price, and the depreciation of the profit does not always elicit a negative response. When investors assess the company's profit information, investors not only see a small amount of profit but will consider the quality of the profit formed [16]. On the other hand, also strengthens that the market response when interpreting profit information that appears is quite divergent depending on the reliability, confidence and expectations of investors, as well as good quality of information [17].

The existence of a fairly divergent market response in considering the quality of profit indicates that profit information still has limitations. This limitation is likely influenced by calculations that can be cheated for the manager of the company so that it takes an appropriate instrument in identifying earnings quality and stock return by using the coefficient of profit response / Earnings Response Coefficient [18].

Research on earnings response coefficient is still very popular among academics. Some of them have been done by Tamara \& Suaryana, Ahabba \& Sebrina, Fitriah, Ramadanti \& Rahayu, Febrilyantri \& Istianingsih, Saputra \& Mulyani. From these studies showed that there are a variety of factors such as growth opportunity, leverage, accrual quality, profitability, capital structure, size, earnings persistance, and intellectual capital that can influence the variable earnings response coefficient.

Based on the study, the researchers saw the inconsistency of the findings of different research results on variable growth opportunities, earnings persistance, intellectual capital against variable earnings response coefficient, therefore researchers are encouraged to carry out further deepening. In this research, researchers made an update by choosing IDX30 indexed companies in 2017-2019 as the object of research, because IDX-30 members are active companies with strong market fundamentals and capital. Based on the findings of background phenomena that researchers have described before, the researchers carried the title of the study "Understanding Earnings Response Coefficient from Growth Opportunities, Earnings Persistance, and Intellectual Capital; Empirical Study from IDX-30 Indexed Companies”. 


\section{LITERATURE REVIEWS}

\subsection{Signalling Theory}

Figure 1 : Conceptual Framework

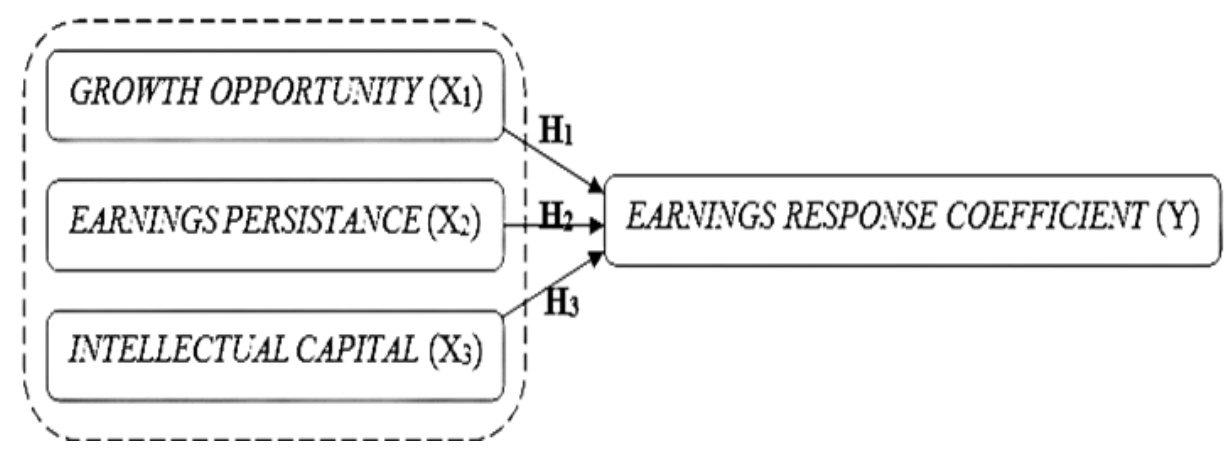

According to [19] illustrates the signal as a corporate management behavior that conveys instructions to investors on how management views a prospect within the company. The information is important to the investor and business practitioner, specially because provides the explanation, notes or descriptions, either for the past, the present of the future for the company's life sustainability and how the effect to the company. By using signal theory, asymmetric information will be easier to reduce because the detection of a signal can show a hidden characteristic of the signaler [20].

\subsection{Market Efficiency}

According to [21] Market Efficiency should be associated with a collection of information to determine the share price for market participants such as information procurement mechanisms with various regulations applicable in the scope of capital market operations. Fama divides market efficiency into three forms, among others strong form market efficiency, semistrong form market efficiency, and weak form market efficiency [22].

\subsection{Resource Based Theory (RBT)}

RBT theory informs that an issuer actually has resources that can be an endorsement for the competitiveness of the issuer as well as a focus towards a good long-term performance direction. Barney suggests that potential corporate resources must have four attributes, including valuable resources, rare resources, imperfectly imitable resources, and nonsubstitutability resources [20].

The increase in the amount of property in the company's financial statements can reflect the company's larger growth opportunities, because the company will get an increase in terms of profits and have stability, and be able to increase the return in the next period [23]. In line with this thought, Tamara \&
Suaryana suggested that there is a positive influence between growth opportunities and earnings response coefficient because companies with high growth opportunities will get a greater response from investors because companies with high growth opportunities will get a greater response from investors [11]. This is because companies with high growth opportunities will provide greater profits to investors in the future.

$\mathrm{H}_{1}$ : Growth Opportunities have a positive effect on Earnings Response Coefficient.

Earnings persistance describes the qualitative relevance characteristics of a company's profit quality. In line with these arguments, Canina \& Potter asserts that strong persistence indicates a continuous profit formation process [24]. Large earnings persistance can trigger a market reaction, because high earnings persistance is able to convince investors to react more quickly in determining decisions. The results of Wahyuni \& Damayanti inform that a strong market reaction will signal to investors, because they believe the company's profits can continue to grow or remain stable in the future [25]. This is based on signalling theory predictions, where there is a difference in status between companies that provide good information and companies that do not have good news as a benchmark of future performance so that those who have poor financial performance in the past will not be trusted by the market.

$\mathrm{H}_{2}$ : Earnings Persistance have a positive affects Earnings Response Coefficient.

Intelectual Capital (IC) can be projected through VAIC values. The amount of VAIC value is directly proportional to the value of earning response 
coefficient, because investors will be more confident to respond to positive information when there is a VAIC advantage in the company, so that the correlation between earnings and returns that occur in the market response is positively able to affect the value of earning response coefficient [26]. Febrilyantri \& Istianingsih believes that efficient market conditions can encourage the role of intellectual capital in improving the company's value and financial performance [27]. Agustiningrum suggests that intellectual capital can be an input of information responded by investors when they reflect on the decision of the stock price traded, because companies that perform well will tend to disclose intellectual capital more and transparently. Thus, the greater the VAIC, the greater the ERC value [28].

$\mathrm{H}_{3}$ : Intellectual Capital has a positive influence on Earnings Response Coefficient.

\section{RESEARCH METHODS}

Researchers determined all IDX-30 indexed companies in IDX in 2017-2019 as the population in this research amounted to 45 Companies. In this research, researchers used a non-random sample method with purposive sampling techniques. Based on these benchmarks, researchers obtained samples of 17 companies. Researchers collect data using documentation methods, with the stages of tracing, reading and quoting then the data is processed to be sorted according to the benchmarks described above [29]. The data researchers obtained through financial statements published https://idx.co.id/.

\section{DATA ANALYSIS}

Table 2. Output Statistic Descriptive

\section{Descriptive Statistics}

\begin{tabular}{|l|r|r|r|r|r|}
\hline & \multicolumn{1}{|c|}{ N } & Minimum & Maximum & Mean & Std. Deviation \\
\hline GO & 51 & -7820 & 1,5595 &, 096057 &, 3302496 \\
EP & 51 & $-3,6665$ & 3,1571 &, 513471 & 1,0084850 \\
VAIC & 51 & 2,2940 & 11,1492 & 4,272043 & 1,7965540 \\
ERC & 51 & $-1,0352$ & 1,7136 &, 129335 &, 5760728 \\
Valid N (listwise) & 51 & & & & \\
\hline
\end{tabular}

The output results of Table 2 inform that there are 51 sample data on annual financial statements used in this study. The Growth Opportunities (GO) variable has an average value of 0.096057 , meaning that the achievement of benefits from the company's operational activities as reflected by changes in the company's assets is $9.6057 \%$. The highest score of 1.5595 was achieved by PT. Unilever Indonesia in 2018, while the lowest score was -0.7820 by PT. Telkom Indonesia in
2018. The standard deviation value of 0.3302496 means the spread of growth opportunities variables is $33.02496 \%$.

The Earnings Persistence (EP) variable has an average value of 0.513471 , meaning that the company's sustainable profit stability for the year is $51.3471 \%$. The highest score of 3.1571 was achieved by PT. Indofood Sukses Makmur in 2017, while the lowest score was 3.6665 by PT. Unilever Indonesia in 2018. The standard deviation value of 1.0084850 means the spread of the earnings persistence variable is $100.8485 \%$.

The intellectual capital variable which is proxied through the VAIC calculation has an average value of 4.272043 , meaning that the company's intangible asset added value is $427.2043 \%$. The highest score of 11.1492 was achieved by PT. Unilever Indonesia in 2018, while the lowest score was 2.2940 by PT. Perusahaan Gas Negara in 2019. The standard deviation value of 1.7965540 means the spread of intellectual capital variables is $179.65540 \%$.

The Earnings Response Coefficient (ERC) variable has an average of 0.129335 , meaning that the market responsiveness to fluctuations in the company's stock return that occurs is $12.9335 \%$. The highest score of 1.7136 was achieved by PT. Kalbe Farma in 2019, while the lowest score was -1.0352 by PT. Bank Rakyat Indonesia 2019. The standard deviation value of 0.5760728 means the spread of the earnings response coefficient variable is $57.60728 \%$.

Table 3. Normality Test

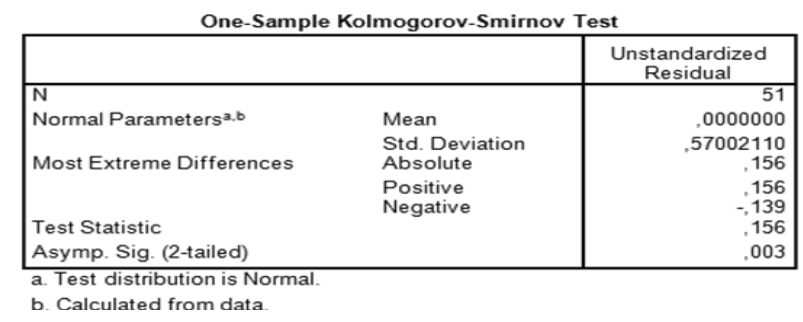

The normality test in this research was carried out twice, because in the first test the asymp.sig value was found to be $0.003(0.003<0.05)$ which was not normally distributed. Thus, before entering the second test, the researcher first conducted data outliers by eliminating some data that were still extreme. Finally, in the second normality test, 43 samples were normally distributed with an asymp.sig value of 0.737 
Figure 2 Scatterplot

Table 4. Normality II

\begin{tabular}{|c|c|c|}
\hline & & $\begin{array}{c}\text { Unstandardized } \\
\text { Residual } \\
\end{array}$ \\
\hline $\begin{array}{l}\text { N } \\
\text { Normal Parameters }\end{array}$ & $\begin{array}{l}\text { Mean } \\
\text { Std. Deviation }\end{array}$ & $\begin{array}{r}43 \\
, 0000000 \\
, 28087707\end{array}$ \\
\hline $\begin{array}{l}\text { Most Extreme Differences } \\
\text { Kolmogorov-Smirnov Z } \\
\text { Asymp. Sig. (2-tailed) }\end{array}$ & $\begin{array}{l}\text { Absolute } \\
\text { Positive } \\
\text { Negative }\end{array}$ & $\begin{array}{r}, 104 \\
, 104 \\
-, 058 \\
, 685 \\
, 737\end{array}$ \\
\hline
\end{tabular}

Table 5. Multicolinearity Test

Coefficients a

\begin{tabular}{|ll|r|r|}
\hline \multirow{2}{*}{ Model } & \multicolumn{2}{|c|}{ Collinearity Statistics } \\
\cline { 3 - 4 } & & Tolerance & \multicolumn{1}{l|}{ VIF } \\
\hline 1 & GO &, 857 & 1,167 \\
& EP &, 768 & 1,302 \\
& VAIC &, 768 & 1,302 \\
\hline
\end{tabular}

a. Dependent Variable: ERC

Table 5 informs the Tolerance value for each independent variable GO, EP, and VAIC, respectively $0.857 ; 0.768 ; 0.768$ whose value is still $>0.01$, on the right side of the VIF value for each independent variable GO, EP, and VAIC respectively. -1.167;1.302;1.302, whose value is still $<10$. So, it has been proven that there are no signs of multicollinearity in the independent variables of this journal.

Table 6. Autocorrelation Output

Model Summary $b$

\begin{tabular}{|l|r|r|r|r|r|}
\hline Model & $R$ & R Square & \multicolumn{1}{|c|}{$\begin{array}{c}\text { Adjusted R } \\
\text { Square }\end{array}$} & $\begin{array}{c}\text { Std. Error of } \\
\text { the Estimate }\end{array}$ & $\begin{array}{l}\text { Durbin- } \\
\text { Watson }\end{array}$ \\
\hline 1 &, 473 a & 223 &, 164 &, 2914799 & 2,157 \\
\hline
\end{tabular}

a. Predictors: (Constant), VAIC, GO, EP

b. Dependent Variable: ERC

Based on table 6, the DW value is 2.157. Based on the values in the attached DW table, it can be seen that the values of DU and (4-DU) are 1.6632 and 2.3368 , respectively. Thus DU $>\mathrm{DW}<(4-\mathrm{DU})$ so that the fit model of this research escapes autocorrelation.

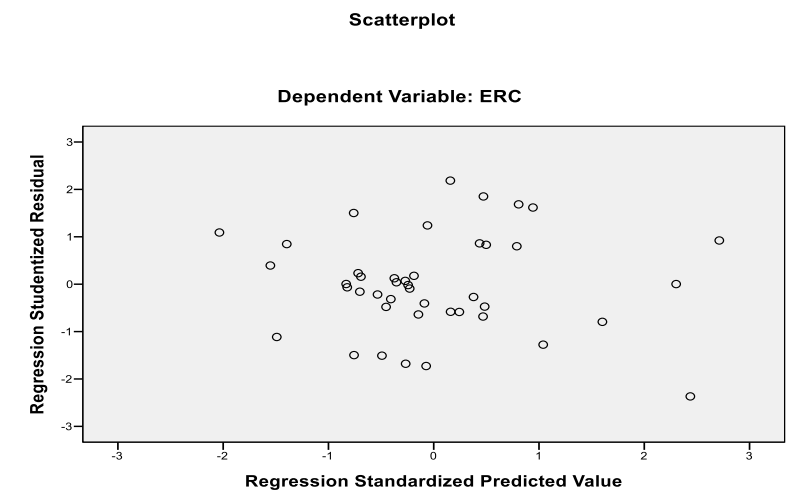

Based on the graph, the scatterplot in Figure 2 shows the distribution of the data points spread around the number zero and does not resemble a wavy and narrowed pattern and should not be clustered in one place either above or below. In order to be more sure whether heteroscedasticity appears or not, the researcher again conducted the glejser test. Sig $<0.05$ indicates that the fit model is free from heteroscedasticity [30]. Here's the output of the glejser test:

Table 7. Glejser

\section{ANOVAb}

\begin{tabular}{|rl|r|r|r|r|r|}
\hline \multicolumn{2}{|l|}{ Model } & \multicolumn{1}{|c|}{$\begin{array}{c}\text { Sum of } \\
\text { Squares }\end{array}$} & df & Mean Square & F & Sig. \\
\hline 1 & Regression &, 953 & 3 &, 318 & 3,738 &, $019 \mathrm{a}$ \\
& Residual & 3,313 & 39 &, 085 & & \\
& Total & 4,266 & 42 & & & \\
\hline
\end{tabular}

a. Predictors: (Constant), VAIC, GO, EP

b. Dependent Variable: ERC

Based on the information in table 7, the sig values of GO, EP, and VAIC are $0.745 ; 0.157 ; 0.858$. So, it has been proven that the three independent variables are free from heteroscedasticity because the significance value exceeds 0.05 .

Table 8. Regression Output

\begin{tabular}{|c|c|c|c|}
\hline \multicolumn{4}{|c|}{ Coefficients $^{\mathrm{a}}$} \\
\hline \multirow{2}{*}{\multicolumn{2}{|c|}{ Model }} & \multicolumn{2}{|c|}{ Unstandardized Coefficients } \\
\hline & & $\mathrm{B}$ & Std. Error \\
\hline \multirow[t]{4}{*}{1} & (Constant) &,- 066 & 136 \\
\hline & GO &, 164 &, 138 \\
\hline & EP & 159 & 049 \\
\hline & VAIC &, 017 &, 027 \\
\hline
\end{tabular}

a. Dependent Variable: ERC 
$Y=-0,066+0,164 X_{1}+0,159 X_{2}+0,017 X_{3}+\varepsilon$

$\alpha=$ Alpha of -0.066 indicates when all independent variables are constant at zero, then the earnings response coefficient value is -0.066 units.

$\beta \mathrm{X} 1=$ The coefficient of growth opportunities variable has a positive value of 0.164 , meaning that for every $1 \%$ addition to the value of growth opportunities, it will increase 0.164 units of earnings response coefficient.

$\beta \mathrm{X} 2=$ The coefficient of earnings persistence variable has a positive value of 0.159 , meaning that every $1 \%$ addition to the value of growth earnings persistence will increase 0.159 units of earnings response coefficient.

$\beta \mathrm{X} 3=$ The intellectual capital variable coefficient has a positive value of 0.017 , meaning that every $1 \%$ addition to the value of growth earnings persistence will increase 0.017 units of earnings response coefficient.

Table 9. Goodness of Fit Test

ANOVAb

\begin{tabular}{|c|c|c|c|c|c|c|}
\hline \multicolumn{2}{|c|}{ Model } & $\begin{array}{l}\text { Sum of } \\
\text { Squares }\end{array}$ & df & Mean Square & $\mathrm{F}$ & Sig. \\
\hline \multirow[t]{3}{*}{1} & Regression &, 953 & 3 &, 318 & 3,738 &, $019 a$ \\
\hline & Residual & 3,313 & 39 & ,085 & & \\
\hline & Total & 4,266 & 42 & & & \\
\hline
\end{tabular}

a. Predictors: (Constant), VAIC, GO, EP

b. Dependent Variable: ERC

Table 9 shows the $\mathrm{F}$ test sig value of 0.019 . The test value is below zero point zero five, meaning that this research model is significant or the effect of the dependent variable is independent simultaneously. So the regression model used in this research is feasible to be used in research testing.

Table 10. t Test

\section{Coefficient .}

\begin{tabular}{|c|c|c|c|}
\hline \multicolumn{2}{|c|}{ Model } & $\mathrm{t}$ & Sig. \\
\hline \multirow[t]{4}{*}{1} & (Constant) &,- 485 & ,631 \\
\hline & $\mathrm{GO}$ & 1,188 & ,242 \\
\hline & EP & 3,266 &, 002 \\
\hline & VAIC &, 617 &, 541 \\
\hline
\end{tabular}

a. Dependent Variable: ERC
Based on the information in table 10, the information that can be obtained is:

The t-test output shows the sig value of the Growth Opportunities (GO) variable of 0.242 . The magnitude of the sig value in the GO variable is higher than the significance level so that the $\mathrm{H}_{1}$ assumption in IDX 30 2017 - 2019 indexed companies is rejected.

The output of the t test shows the sig value of the Earnings Persistance (EP) variable of 0.002. The magnitude of the sig value on the EP variable is smaller than the significance level so that the $\mathrm{H}_{2}$ assumption which reads, "Earnings persistence has a positive effect on the earnings response coefficient in IDX 30 indexed companies in 2017 - 2019" is accepted.

The t-test output shows the sig value of the Intellectual Capital variable which is proxies through the VAIC of 0.541. The magnitude of the sig value on the VAIC is higher than the significance level so that the $\mathrm{H}_{3}$ assumption which reads, "Intellectual capital has a positive effect on the earnings response coefficient in IDX 30 indexed companies in 2017 - 2019" is rejected.

Table 11. Chi Square Output

Model Summary b

\begin{tabular}{|l|l|l|r|r|}
\hline Model & $\mathrm{R}$ & R Square & \multicolumn{1}{|c|}{$\begin{array}{c}\text { Adjusted R } \\
\text { Square }\end{array}$} & $\begin{array}{c}\text { Std. Error of } \\
\text { the Estimate }\end{array}$ \\
\hline 1 &, $473 \mathrm{a}$ &, 223 &, 164 &, 2914799 \\
\hline
\end{tabular}

a. Predictors: (Constant), VAIC, GO, EP

b. Dependent Variable: ERC

The output from Table 11 indicates the magnitude of the adjusted R-Square in this study is 0.164 , meaning that $16.4 \%$ of the earnings response coefficient can be explained by growth opportunities, earnings persistence, and intellectual capital, but the remaining $83.6 \%$ can be explained by other factors.

\section{RESULT AND DISCUSSION}

The output of this study informs that the Growth Opportunities (GO) variable has no effect on the earnings response coefficient variable in IDX-30 indexed companies listed on the Indonesia Stock Exchange in 2017-2019. This statement is supported because the results of the GO statistical $t$ are $0.242>$ 0.025 , so $\mathrm{H}_{1}$ is rejected. Changes in the amount of property in the financial statements can reflect the go of the larger company, because the company will get an increase in terms of profits and have stability, and be able to increase the return in the next period. But reality answers that high Growth Opportunities (GO) does not necessarily guarantee greater profits to investors in the future so it is less likely that companies with large GO can get a higher response from investors. Because to achieve high corporate growth opportunities usually 
require funds that are not small, so that the company's operations can continue to grow through investments in tangible assets, so it does not rule out the possibility that the profits received will be more likely to be allocated to the company's growth financing rather than distributed to investors, so that the company does not experience underinvestment.

The output of this study proves that the Earnings Persistance (EP) variable has a significant effect on the variable earnings response coefficient in IDX-30 indexed companies listed on the Indonesia Stock Exchange in 2017-2019. The statement is corroborated by the ep significance result on the statistical test $\mathrm{t}$ worth $0.002<0.025$, so that $\mathrm{H}_{2}$ is accepted.Based on these findings, it turns out that it can be proven that the influence of large earnings persistance can trigger market reactions, because the high earnings persistance is able to convince investors to react more quickly in determining decisions. In line with the presentation of Wahyuni \& Damayanti that a strong market reaction will give a signal to investors, because they believe the company's profits can continue to grow or remain stable in the future [25]. The role of earnings persistance is important in looking at the consistency of the quality of profits generated by the company as a clue that the company can maintain its profits over time. Thus it can be concluded that if the company's reported profit is persistent then the ERC value is expected to be higher.

The output of this study informs that the Intellectual Capital (IC) variable has no influence on the variable earnings response coefficient in IDX-30 indexed companies listed on the Indonesia Stock Exchange in 2017-2019. The statement was supported by vaic significance results on statistical tests worth $0.541>$ 0.025 , so $\mathrm{H}_{3}$ was rejected. Resource Based Theory (RBT) which makes knowledge resources as the most significant and strategic value added in the utilization of all capabilities in the company, both human capital, structural capital, and customer capital from the company is not proven from the results of this research. The low influence of IC on ERC is due to companies still taking conventional ways such as natural resources, financial resources in building their business and not based on knowledge that can be functioned as added value when decision making, so the lack of understanding in the application of ic measurement standardization makes investors have not been sufficiently able to calculate appropriately the IC owned by the company in investing. Thus, these results illustrate a condition where the intellectual capital value of unresponsible companies for investors.

\section{CONCLUSION}

Growth opportunities have no significant effect on the earnings response coefficient in IDX 30 indexed companies in 2017-2019. Earnings persistence has a positive influence on the earnings response coefficient in IDX 30 indexed companies in 2017 - 2019. Intellectual capital does not have a significant impact on the earnings response coefficient in IDX 30 indexed companies in 2017-2019.

The tendency of allocating profit funds to finance the company's operations is important, but this step should be considered more carefully because to achieve high growth opportunities the company requires large amounts of funds, so the distribution of the company's short-term income to investors should be improved both in terms of profits as well as stability.

The positive effect that appears on earnings persistence on earnings response coefficient can be used as a credible fundamental indicator instrument for investors in investment decisions.

Modernization of value creation must be more actively implemented in a comprehensive manner in an effort to encourage the success of the company's intellectual resources business activities that are sustainable.

\section{ACKNOWLEDGMENTS}

Thank you to my lectures, Mrs. Dien and Mr. Baihaqi who have been patiently guiding, giving my direction and motivation in completing this journal. What a very rewarding experience.

\section{REFERENCES}

[1] Nugroho AC, Andriani RS. Rekomendasi Saham dan Pergerakan IHSG Hari Ini, 20 Januari 2020. Bisnis 2020.

[2] Widiantoro DW. IHSG Jatuh ke Level 5.361. Kompas 2020.

[3] Sutarno. Berburu Saham saat Covid-19, Pilih Emiten Prudent. Ini Cirinya. Bisnis 2020.

[4] Pratomo MN, Utami DN, Ulfah FU. Jadi Acuan Investasi, Saham Baru Indeks LQ45 dan IDX30 Gairahkan Bursa. Mark Bisnis 2020.

[5] Sitinjak ELM. Diskusi Rutin Bersama Hadapi Covid-19 oleh Unika. Semarang: Semarang: Universitas Katolik Soegijapranata; 2020.

[6] Sari NL, Daud RM. Pengaruh Informasi Laba Terhadap Koefisien Respon Laba (Studi Empiris Pada Perusahaan Manufaktur Yang Terdaftar Di BEI Pada Tahun 2011-2014). J Ilm Mhs Ekon Akunt 2016;1:227-36.

[7] Indonesia BE. Laporan Keuangan BBNI 2019. Jakarta: 2020.

[8] Indonesia BE. Laporan Keuangan BBNI 2018. Jakarta: 2019.

[9] Indonesia BE. Laporan Keuangan UNTR 2019. 
Jakarta: 2020.

[10] Indonesia BE. Laporan Keuangan UNTR 2018. Jakarta: 2019.

[11] Tamara IGAAA, Suaryana IGNA. Pengaruh Growth Opportunity dan Leverage pada Earning Response Coefficient. E-Jurnal Akunt 2020;30:1414-24.

[12] Fitriah S. Pengaruh Kesempatan Bertumbuh Dan Leverage Terhadap Earnings Response Coefficient Sektor Property dan Real Estate Terdaftar di Bursa Efek Indonesia. J Stud Akunt Dan Keuang 2020;3:15-30.

[13] Indonesia BE. Laporan Keuangan BBCA 2019. Jakarta: 2020.

[14] Indonesia BE. Laporan Keuangan INTP 2019. Jakarta: 2020.

[15] Indonesia BE. Laporan Keuangan GGRM 2019. Kediri: 2020.

[16] Ahabba B, Sebrina N. Pengaruh Persistensi Laba dan Kualitas Akrual terhadap Earnings Response Coefficient pada Perusahaan Manufaktur dan Keuangan yang Terdaftar di BEI Tahun 2016-2018. J Eksplor Akunt 2020;2:2051-64.

[17] Hariati R. Pengaruh Ukuran Perusahaan, Struktur Modal, dan Pertumbuhan Laba Terhadap Earnings Response Coefficient. Artik Ilm Sekol Tinggi Ilmu Ekon Perbanas 2017:115.

[18] Suardana KA, Dharmadiaksa IB. Earnings Response Coefficient: Analisis Faktor-Faktor Yang Mempengaruhinya. J Ris Akuntansi, JUARA 2018;8:1-10.

[19] Brigham EF, Houston JF. Fundamentals of Financial Management 15 Edition. 15th ed. United States of America: United States of America: Cengage Learning; 2019.

[20] Ulum I. Intellectual Capital Model Pengukuran, Framework Pengungkapan dan Kinerja Organisasi. 3rd ed. Malang: Malang: Penerbit Universitas Muhammadiyah Malang; 2017.

[21] Suwardjono. Teori Akuntansi Perekayasaan Pelaporan Keuangan. Yogyakarta: Yogyakarta: BPFE; 2005.

[22] Jogiyanto. Teori Portofolio dan Analisis Investasi. Yogyakarta: Yogyakarta: BPFE; 2017.

[23] Pangidoan MT, Chusnah FN. Pengaruh Leverage, Kesempatan Bertumbuh dan Profitabilitas Terhadap Koefisien Respon Laba ( Studi pada Perusahaan Barang Konsumsi yang Terdaftar di Bursa Efek Indonesia Tahun 20152019 ). Sekol Tinggi Ilmu Ekon Indones 2020:1-25.
[24] Canina L, Potter G. Determinants of Earnings Persistence and Predictability for Lodging Properties. Cornell Hosp Q 2019;60:40-51.

[25] Wahyuni A, Damayanti CR. Pengaruh Persistensi Laba, Struktur Modal Dan Corporate Social Responsibility (CSR) Terhadap Earning Response Coefficient (ERC) (Studi Pada BUMN yang Terdaftar di BEI dan Menggunakan Pedoman Global Reporting Initiative (GRI) G4 Periode 2013-2016). J Adm Bisnis 2020;78:38-45.

[26] Saputra I, Mulyani S. Pengaruh Intellectual Capital terhadap (ERC) Earning Respons Coefficient pada Perusahaan Perbankan yang Terdaftar di Bursa Efek Indonesia (BEI). J Ekon Dan Bisnis 2016;9:18-34.

[27] Febrilyantri C, Istianingsih. The Influence of Intellectual Capital and Good Corporate Governance on Earnings Response Coefficient (Case Study on Banks listed on IDX 20132015). Int J Sci Res 2018;7:69-76.

[28] Agustiningrum SA. Pengaruh Intellectual Capital, Leverage dan Profitability Terhadap Earning Response Coefficient Dengan Corporate Social Responsibility Disclosure Sebagai Moderating Variable Pada Perusahaan Indeks LQ-45 Terdaftar Di Bei Tahun 20152019. Artikel Ilmiah. Sekolah Tinggi Ilmu Ekonomi Perbanas. Surabaya, 2020.

[29] Husna A, Suryana B. Metodologi Penelitian dan Statistik. Jakarta: Jakarta: Kementerian Kesehatan Republik Indonesia; 2017.

[30] Ghozali I. Aplikasi Analisis Multivariate Dengan SPSS. Semarang: Semarang: Badan Penerbit Universitas Diponegoro; 2018. 